\title{
Infancia y dictadura: los niños ante el terrorismo de Estado en el cine argentino
}

Ximena Triquell

Universidad Nacional de Córdoba - CONICET

\section{Resumen}

El presente trabajo forma parte de un proyecto mayor cuyo principal objetivo es analizar diferentes representaciones de la infancia en el cine argentino, con el objetivo de observar de qué manera tales representaciones guardan relación con el momento histórico de su producción.

En este trabajo abordamos la representación de niños en relación con la dictadura a partir de tres ejes: a) como «objetos» de disputa, en una lógica de posesión o carencia, que refiere directamente a la apropiación de bebés y niños por parte de los militares; como sucede en La historia oficial (Puenzo, 1985) o, casi dos décadas después, en Cautiva (Biraben, 2005); b) como pequeños adultos de quienes se espera que afronten la realidad, incluida la militancia de los padres, del mismo modo que lo hacen éstos - Un lugar en el mundo (Aristarain, 1992), Kamtchatka (Piñeyro, 2002) y separada también
Palabras clave:

cine argentino, infancia en cine, dictadura. 
por una década Infancia clandestina (Ávila, 20I2)—; y

c) como sujetos que miran a los adultos como por ejemplo en Un muro de silencio (Stantic, 1993) o Amigomio (Meerapfel, 1994).

\section{Abstract}

This paper is part of a larger project whose main objective is to analyze different representations of childhood in Argentine cinema, in order to understand how such representations are related to the historical moment of their production.

In this work we focus on the representation of children in relation to the $1976-1983$ dictatorship regarding three lines: to) as «objects» of dispute, in a logic of possession or lack, which refers to the appropriation of infants and children by the military - as in La historia oficial (Puenzo, 1985) or, almost two decades later, in Cautiva (Biraben, 2005); (b) as small adults who are expected to face reality, including their parents' militancy, in the same way they do - Kamtchatka (Piñeyro, 2002) and separated by a decade, Infancia clandestina (Ávila, 20I2); and c) as subjects that watch adults, as in Un muro de silencio (Stantic, 1993) or Amigomío (Meerapfel, 1994).

\section{Keywords:}

Argentine cinema, children in film, dictatorship in Argentina.

\section{Introducción}

En este trabajo nos proponemos pensar las representaciones de la infancia en el cine argentino posdictadura. Con el término «representaciones» nos referimos a construcciones discursivas que, más que referir a una realidad previa, la construyen, siempre de determinada manera, siempre a ciertos fines, o lo que es lo mismo no exentas de una dimensión ideológica y de un cierto poder. ${ }^{1}$ A la vez, con el término posdictadura no nos referimos

1. Se percibirá acá el marco teórico del cual partimos que está constituido por la Teoría de los discursos sociales propuesta por Eliseo Verón. No profundizamos en estos principios en este trabajo ya que éstos pueden leerse en otros -múltiples- lugares. 